Oliveira, C.A.F. Perspectivas para construção participativa do Ecoturismo de base comunitária na Resex Cassurubá. Anais do VIII Congresso Nacional de Ecoturismo e do IV Encontro Interdisciplinar de Ecoturismo em Unidades de Conservação. Revista Brasileira de Ecoturismo, São Paulo, v.4, n.4, 2011 , p. 543.

\title{
PERSPECTIVAS PARA CONSTRUÇÃO PARTICIPATIVA DO ECOTURISMO DE BASE COMUNITÁRIA NA RESEX CASSURUBÁ
}

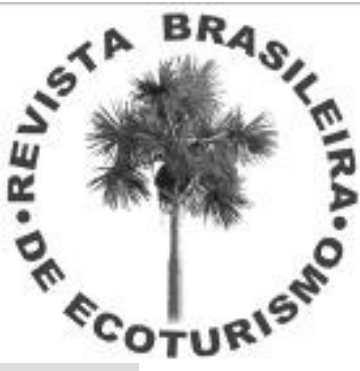

\author{
Carlos Alfredo Ferraz de Oliveira* \\ *Universidade Estadual de Santa Cruz \\ E-mail: cferrazgp99@yahoo.com.br
}

Nos municípios de Caravelas e Nova Viçosa, extremo sul da Bahia, existe o complexo estuarino Cassurubá que, por sua importância social, cultural e ambiental, está inserido na área da recém criada Reserva Extrativista Cassurubá. Nesta unidade de conservação de uso sustentável está sendo proposto um projeto de ecoturismo de base comunitária que envolve 15 famílias ribeirinhas e 13 instituições atuantes na localidade. A finalidade do projeto é iniciar a implantação deste tipo de turismo proporcionando uma ferramenta para o protagonismo comunitário. Com objetivo de analisar os limites e oportunidades para construção participativa do ecoturismo de base comunitária nesta área, foi realizada uma pesquisa descritiva com abordagem interpretativa utilizando métodos qualitativos para coleta e análise dos dados. A coleta dos dados ocorreu através de estudos bibliográficos e documentais, observação participante e entrevistas semi-estruturadas e estruturadas. A análise qualitativa dos dados coletados resultou na identificação da organização social das famílias ribeirinhas e suas opiniões sobre esta unidade de conservação e o projeto. Com a melhor compreensão dos modos de vida e das opiniões das famílias, foi possível contextualizar as percepções das famílias ribeirinhas envolvidas durante a execução da proposta e identificar os níveis de participação que estes tiveram nas ações do projeto. Estas identificações possibilitaram indicar e explanar sobre os limites e oportunidades para construção participativa do ecoturismo de base comunitária na Unidade de Conservação (UC). Foram sugeridas ações em prol da sustentabilidade da UC e diretrizes para recriação, renovação e diferenciação das atividades socioeconômicas na área protegida.

Palavras-chave: RESEX Cassurubá; Ecoturismo; Ribeirinhos. 